\title{
AN INTERESTING YOUNG VELELLA IN THE PLYMOUTH PLANKTON
}

\author{
By Marie V. Lebour, D.Sc. \\ From the Plymouth Laboratory
}

(Text-fig. I)

On 2 February I943, after some very fierce south-westerly storms, a curious object was found in the inshore plankton which proved to be the 'float' of a very young Velella in the Rataria stage. In order to be certain of its identity some small complete Velellas were compared. These were kindly sent by Miss Delap of Valencia, to whom I am much indebted. They ranged from I. 5 to $2 \mathrm{~mm}$. across and were very similar to the young forms described and figured by Huxley (1858), who identified them with the Rataria of Eschscholz (1829). In this stage the float is growing and may already have the crest, a soft, much higher structure, projecting above it. In order to see the float clearly one of the Irish specimens, $2 \mathrm{~mm}$. across, was macerated in $10 \%$ caustic potash, the float separating out and proving to be exactly similar to the Plymouth specimen.

The peculiar structure of this float and the fact that the available figures of the Rataria of similar size show only the external features make a short note desirable, for in the existing figures one cannot be certain of the exact extent and position of the float. So difficult was it to decipher that, although it seemed very probable that we had the float of a Velella, it was not possible at first to be certain.

The float (Fig. I) which was obtained at Plymouth measured 2.4 by $\mathrm{I} \cdot 6 \mathrm{~mm}$., was of an oval shape in surface view, divided obliquely by a high ridge (the crest), and indented at right angles to this. A clear central portion is surrounded by concentric lamellae, pierced by a series of apertures in the region of the crest. Examined sideways the crest was seen to be pinched off from the upper portion, and a central inner cone was attached to the clear central portion. A very small amount of the soft parts of the animal remained, chiefly as dried up tentacles round the inner cone. On comparing the float from the Irish specimen the two corresponded exactly and the position of the float in the whole animal is clear. The covering of the crest is prolonged dorsally into a soft upper crest with canals running down it as in Huxley's figures. The inner cone of the float contains the 'liver' region, and this cone is the beginning of the floor of the float which becomes much flatter as it grows and as the space between is gradually closed up, the whole of the polyp portion with the tentacles lying within the cone. Thus eventually the float is composed 
of the two layers as already known. Specimens from Ireland hardly more than I mm. across had a very much smaller float with no concentric lamellae, showing that the float must grow very quickly. The specimen which was macerated had its stomach full of harpacticid copepods, a common food, as already known, and there were also two nematodes, probably parasitic.

The extremely interesting life history of Velella has been well interpreted by Woltereck (1904), who found the earliest larva (Conaria) in the deep waters of the Mediterranean, having the red colour usually found in such deep water animals. He followed the changes from this Conaria from deep waters up to
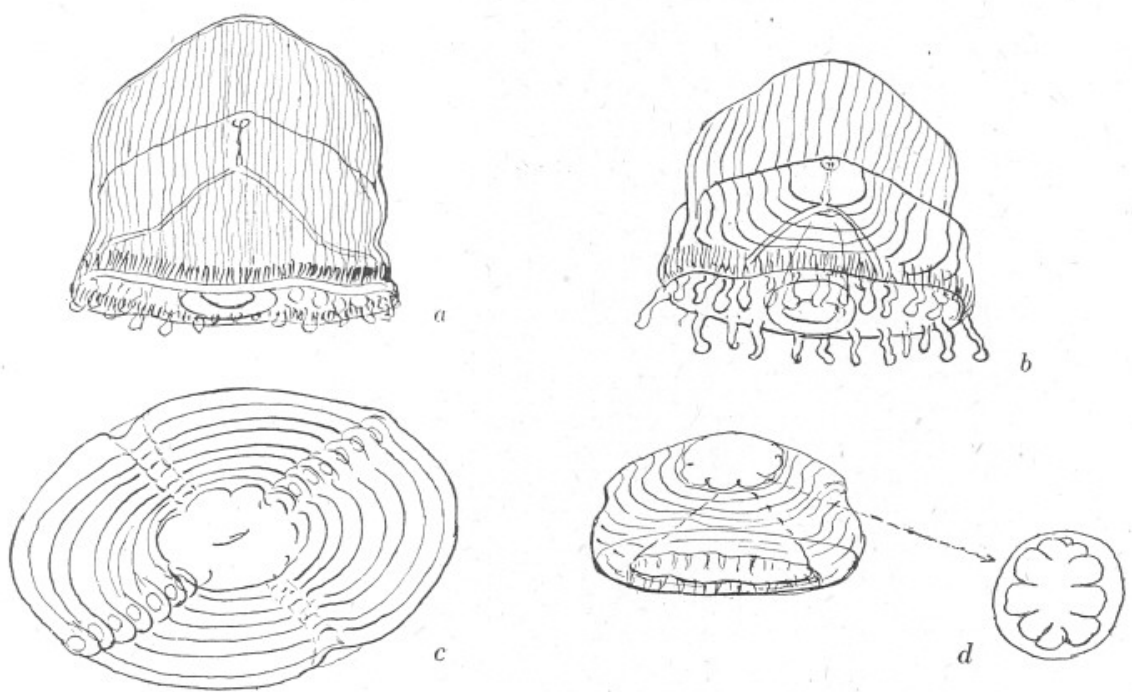

Fig. I. Young Velella and float. $a, 2 \mathrm{~mm}$. across, untreated (from Miss Delap, Valencia Island, 1904). $b, 2 \mathrm{~mm}$. across, partly treated with caustic potash to show float (from Miss Delap, Valencia Island, I904). c, float of Velella from Plymouth (4 February 1943), $2.4 \mathrm{~mm}$. across from above. $d$, the same from the side.

the surface-living purple Rataria - a truly wonderful metamorphosis. Swarms of Velella occur occasionally near our coasts after violent storms. In Plymouth they have been known to occur in March, October, June and September, and always after storms (see Plymouth Marine Fauna, I93I). Russell \& Kemp (I932) attribute these invasions either to an indication of wind drift of surface water, or an increase of flow in Atlantic water. Even the presence of this one small float of Velella is of interest in this connexion, for it must mean that somewhere near this organism was present in abundance. The fact that such a very young float was found so close inshore in the Plymouth plankton is also of great interest, considering that the young usually occur in much more open waters. 


\section{REFERENCES}

Eschscholz, 1829. System der Acelephen, eine ausführliche Beschreibung aller Medusenartigen Strahlthiere. (Not seen.)

HuxuEy, T. H., I858. The Oceanic Hydrozoa. Ray Society, pp. I-I4I.

Russell, F. S. \& KeMP, S., I932. Pelagic Animals off the South-West Coasts of the British Isles. Nature, Vol. I30, p. 664.

WOLTERECK, R., I904. Ueber die Entwicklung der Velella aus einer in der Tiefe vorkommenden Larve. Zool. Fahrb., Supp. vir, Festschrift A. Weismann, pp. $347-72$. 